\title{
PROFIL PEMAHAMAN KONSEP OPERASI PECAHAN BENTUK ALJABAR SISWA KELAS VIII MTS BINA POTENSI SIS ALJUFRI TATURA PALU
}

\author{
Syamsudin $^{1)}$, Evie awuy ${ }^{2)}$, Sukayasa ${ }^{3)}$ \\ alfatihsyamsudin@gmail.com ${ }^{1)}$,Evieawuy1103@gmail.com ${ }^{2)}$,Sukayasa08@yahoo.co.id ${ }^{3)}$
}

\begin{abstract}
Abstrak: Penelitian ini bertujuan untuk mendiskripsikan pemahaman konsep operasi pecahan bentuk aljabar siswa kelas VIII MTs Bina Potensi Sis Aljufri Tatura Palu. Jenis penelitian ini adalah penelitian kualitatif. Subjek dalam penelitian ini terdiri dari satu siswa berkemampuan tinggi, satu siswa berkemampuan sedang dan satu siswa berkemampuan rendah. Hasil dari penelitian ini yaitu saat menyajikan masalah, subjek berkemampuan tinggi, sedang dan rendah menuliskan hal-hal yang diketahui, ditanyakan dan menyajikanya kedalam bentuk matematika, namun subjek berkemampuan rendah salah dalam memahami masalah disebabkan karena kurangnya ketelitian dalam memahami masalah. Selanjutnya dalam mengklasifikasi pecahan bentuk aljabar, subjek berkemampuan tinggi dan subjek berkemampuan sedang mengelompokkan pecahan yang memiliki variabel dan pecahan yang tidak memiliki variabel. Kemudian dalam memberi contoh pecahan bentuk aljabar dan non-contoh dari pecahan bentuk aljabar, subjek berkemampuan tinggi menjelaskan jenis pecahan bentuk aljabar yaitu memiliki variabel dan koefisien, jika tidak memiliki variabel subjek berkemampuan tinggi menyatakan hanya berbentuk pecahan biasa. Selain hal tersebut subjek berkemampuan tinggi juga menunjukkan dengan tepat yang merupakan pecahan bentuk aljabar. Kemudian dalam menangkap makna suatu masalah subjek berkemampuan tinggi, subjek berkemampuan sedang, menangkap suatu makna operasi penjumlahan, pengurangan, perkalian, dan pembagian pecahan suku-suku sejenis, dan subjek berkemampuan rendah menangkap makna penjumlahan dan perkalian pecahan serta subjek berkemampuan tinggi juga menangkap makna hukum kanselasi (penghapusan). Setelah menangkap makna, subjek menjelaskan kembali objek-objek, sifat-sifat dan fakta serta operasi-operasi tertentu yang digunakan atau dimanfaatkan. Subjek berkemampuan tinggi menjelaskan operasi yang digunakan disertai dengan alasannya dengan baik. Subjek berkemampuan sedang menjelaskan kembali operasi perkalian dan pembagian pecahan bentuk aljabar yang digunakan walaupun dalam proses pelaksanaannya subjek berkemampuan sedang masih belum memahami dengan baik konsep dari perkalian dan pembagian pecahan bentuk aljabar.
\end{abstract}

Kata Kunci: Profil Pemahaman Konsep; Indikator pemahaman konsep; Operasi pecahan bentuk aljabar;

Abstract: This research aims to describe understanding the concept of operation floating the form of algebra students VIII MTs Bina Potensi Sis Aljufri Tatura Palu. The kind of research this is qualitative research. The subject of study take consisting of one students high profile, one students medium profile and one students low profile. The result of this research that was when presents a question, the subject of high profile, while and low wrote known, and elaborated into the form of mathematics, but the subject of low profile wrong in understand a problem because of a lack of thoroughness in understanding problem. Next in the form of classifying floating algebra, the subject of high profile and subject of medium profile group the cracks having variable and crushed not having variable. later an example in the form of algebra fractions and not fractions example of the form of algebra, a type subject of high profile explains fractions namely the form of algebra having variables and coefficients, if not having variable the subject of high profile said only in floating ordinary. Besides this subject of high-profile also shows with appropriate constituting a fraction the form of algebra. Later in grasp the reality a problem the subject of high profile, medium profile, catch a sum meaning operation, reduction, multiplication, and division a floating, and subject of low profile grasp the reality sum and multiplication floating also arrested and subject of high profile meaning law kanselasi (removal). After grasp the reality, the subject of explain back objects, and the fact the properties of operations as well as certain of which are used of and used. The subject of high profile explain an operation used accompanied by the reason was well. The subject of medium profile explain back operation multiplication and division floating the form of algebra that used although in the process of the implementation subject the subject medium profile still not well understand the concept of multiplication and division floating the form of algebra.

Keywords: profile of understanding the concept; Understanding the concept of indicators; operation form algebra; 
Matematika merupakan satu diantara materi yang diajarkan disemua tingkat pendidikan, namun sebagian besar peserta didik beranggapan bahwa belajar matematika itu hanya dengan menghafal rumus lalu menyelesaikan soal dengan rumus yang sudah dihafal melalui operasi hitung dengan bilangan atau angka, huruf, dan simbol saja. Mereka beranggapan bahwa belajar matematika tidak perlu adanya kebermaknaan dan pemahaman konsep. Oleh sebab itu, hasil pembelajaran matematika tidak tersimpan dengan baik dibenak para peserta didik.

Matematika bukanlah ilmu menghafal rumus, karena tanpa memahami konsepnya, rumus-rumus yang telah dihafal tidak akan bermanfaat. Konsep matematika yang abstrak dan berhubungan dengan realitas kehidupan sehari-hari sangatlah penting untuk proses belajar siswa. Menurut Soedjadi (1999), matematika memiliki objek abstrak, bertumpu pada kesepakatan, berpola pikir deduktif, memiliki simbol yang kosong arti, memperhatikan semesta pembicaraan, dan konsisten dalam sistemnya. Sehingga dalam mempelajari matematika siswa harus mengenal dan memahami objek-objek matematika terutama pemahaman konsep. Jika guru terus membiarkan siswa dengan konsep-konsep yang tidak tepat, hal tersebut dapat menimbulkan masalahmasalah dalam proses belajar siswa dimasa yang akan datang, karena konsep matematika yang satu dengan yang lainya saling berkaitan sehingga untuk mempelajarinya harus runtut dan berkesinambungan. Jika siswa telah memahami konsep-konsep matematika maka akan memudahkan siswa dalam mempelajari konsep-konsep matematika berikutnya. Hal ini sejalan dengan pernyataan dari Utari (2012) yang menyatakan bahwa dengan memahami konsep, siswa dapat mengembangkan kemampuannya dalam pembelajaran metematika, siswa dapat menerapkan konsep yang telah dipelajarinya untuk menyelesaikan permasalahan sederhana sampai dengan yang kompleks. Sejalan dengan pendapat Yuanda (2014) yang mengemukakan bahwa dengan memahami konsep akan mempermudah siswa memecahkan masalah matematika yang berkaitan dengan kehidupan sehari-hari.

Operasi pecahan bentuk aljabar merupakan satu diantara materi yang diajarkan di sekolah Menengah Pertama/Madrasah Tsanawiyah di kelas VIII. Banyak sekali manfaat dalam mempelajari operasi pecahan bentuk aljabar terutama dalam kehidupan sehari-hari, namun dibalik banyaknya manfaat dalam mempelajari pecahan bentuk aljabar, masih banyak siswa yang kesulitan dalam mempelajari pecahan bentuk aljabar. Satu diantara penyebab yang menimbulkan kesulitan siswa dalam mengerjakan soal-soal operasi pecahan bentuk aljabar dan membuat jawaban siswa beragam adalah tingkat pemahaman siswa terhadap konsep dalam matematika. Hal ini sejalan dengan pernyataan dari Kumalasari dan putri (2013:1) yang menyatakan bahwa siswa yang mengalami kesulitan dalam mempelajari matematika pada umumnya terletak pada kurangnya pemahaman konsep dan prinsip dalam matematika.

Berdasarkan hasil dialog dengan guru di MTs Bina Potensi, diperoleh informasi bahwa jawaban siswa yang beragam terutama dalam operasi pecahan bentuk aljabar. Oleh karena itu untuk memperkuat informasi dari guru maka peneliti melakukan tes identifikasi. Dari hasil tes identifikasi diperoleh bahwa pemahaman konsep siswa sangat beragam dalam menyelesaikan suatu operasi pecahan bentuk aljabar, sehingga untuk mendapatkan informasi yang lebih akurat mengenai pemahaman konsep siswa maka pemahaman konsep siswa perlu diprofilkan atau digambarkan dalam bentuk deskripsi, kata-kata, dan tulisan secara mendalam agar pemahaman konsep siswa bisa lebih diketahui. Satu diantara upaya agar guru dapat mengatasi kesulitan yang dialami siswa yakni dengan mengetahui gambaran pemahaman konsep siswa tersebut, sehingga guru dapat merancang pembelajaran matematika dengan mempertimbangkan kemampuan masing-masing siswanya termasuk pemahamannnya, agar dalam pembelajaran matematika siswa tidak merasa tertekan dan cenderung memaksakan kemampuannya, yang berakibat siswa beranggapan bahwa matematika sulit dan menakutkan. Gambaran tentang pemahaman konsep seseorang inilah yang disebut dengan profil pemahaman konsep. Hasil tes 
identifikasi tersebut juga diperkuat oleh penelitian yang dilakukan Endah dkk (2016) yang mendeskripsikan pemahaman konsep siswa yang beragam pada materi pecahan bentuk aljabar. Selain itu Endah dkk juga menyimpulkan secara umum bahwa miskonsepsi dapat terjadi pada setiap siswa, baik siswa yang memiliki cara berpikir rendah dalam menyelesaikan permasalahan matematika satu diantaranya yaitu operasi pecahan bentuk aljabar, maupun siswa yang memiliki cara berpikir tinggi dalam pemecahan masalah matematika.

Berdasarkan uraian pada latar belakang, maka rumusan masalah dalam penelitian ini, yaitu bagaimanakah profil pemahaman konsep siswa terhadap operasi pecahan bentuk aljabar?

\section{METODE PENELITIAN}

Jenis penelitian ini adalah penelitian kualitatif dengan pendekatan deskriptif kualitatif yaitu mendeskripsikan profil pemahaman konsep siswa yang berkemampuan tinggi, berkemampuan sedang dan berkemampuan rendah. Subjek dalam penelitian ini ialah siswa kelas VIII Mts Bina Potensi Sis Aljufri Tatura Palu dengan jumlah keseluruhan siswa ialah 41 siswa. Kemudian dipilih subjek dengan skor tertinggi pada kelompok kemampuan tinggi (ST), pada kategori kemampuan sedang diambil subjek yang berada pada skor median (SS), dan skor terendah diambil pada kategori kelompok kemampuan rendah (SR).

Jenis data yang digunakan dalam penelitian ini adalah data kualitatif berupa data tentang profil pemahaman konsep siswa di kelas VIII MTs Bina Potensi Sis Aljufri Tatura Palu yang berkemampuan matematika tinggi (ST), berkemampuan matematika sedang (SS) dan berkemampuan matematika rendah (SR) dalam menyelesaikan operasi pecahan bentuk aljabar berdasarkan indikator pemahaman konsep yang digunakan. Teknik pengumpulan data pada penelitian ini adalah tes dan wawancara. Instrumen penelitian terdiri atas instrumen utama, yaitu peneliti sendiri dan instrumen pendukung yaitu hasil ujian dan tes tertulis yang berisi masalah pecahan bentuk aljabar yang terdiri dari dua soal yaitu M1: Seorang Ayah dan Ibu akan membagikan sejumlah uang kepada kedua anaknya. Anak pertama mendapatkan setengah dari uang Ayah dan mendapatkan tambahan uang Ibu tiga perempat dari uang ayah. Dua perlima dari sisa uang Ayah diberikan kepada anak kedua. Jika jumlah uang Ayah yang tersisa adalah Rp. 12.000,- Berapakah jumlah uang yang dibagikan Ayah dan Ibu kepada kedua anaknya? Jelaskan! M2: Budi dan Anton ingin membagikan sejumlah uang untuk keperluan membuat makalah kepada Rani dan Ani. Rani mendapatkan dua pertiga uang dari Budi dan mendapatkan tambahan uang Anton sejumlah tiga perempat uang Budi. Ani mendapatkan satu perempat dari sisa uang Budi. Jika jumlah uang Budi yang tersisa adalah Rp.2000,- Berapakah jumlah uang yang dibagikan oleh Budi dan Anton? jelaskan!

Analisis data dilakukan dengan mengacu pada analisis data kualitatif model Miles dan Huberman (1992) yaitu: data reduction (reduksi data), data display (penyajian data) dan conclusion/verification (penarikan kesimpulan). Pengujian kredibilitas data yang digunakan pada penelitian ini adalah triangulasi waktu, yaitu teknik pengujian kredibilitas data dengan cara memperoleh data dari sumber yang sama dengan masalah yang setara dalam waktu yang berbeda.

\section{HASIL PENELITIAN}

Hasil pengelompokkan siswa yaitu 6 siswa berkemampuan matematika tinggi, 21 siswa berkemampuan matematika sedang, dan 14 siswa yang berkemampuan matematika rendah. Dari setiap tingkat kemampuan matematika dipilih masing-masing satu siswa berdasarkan teknik acuan normal. Menguji kredibilitas data dilakukan menggunakan tringulasi waktu 
dengan memberikan dua masalah yang setara pada waktu yang berbeda yaitu M1 dan M2. Kedua masalah tersebut telah kredibel. Data yang dianalisis dalam penelitian ini adalah tentang profil pemahaman konsep siswa berdasarkan indikator pemahaman konsep dalam menyelesaikan M1.

\section{Profil Pemahaman Konsep Operasi Pecahan Bentuk Aljabar Subjek Berkemampuan Tinggi (ST).}

Jawaban ST dalam menyajikan masalah sebagaimana ditunjukkan pada Gambar 1.

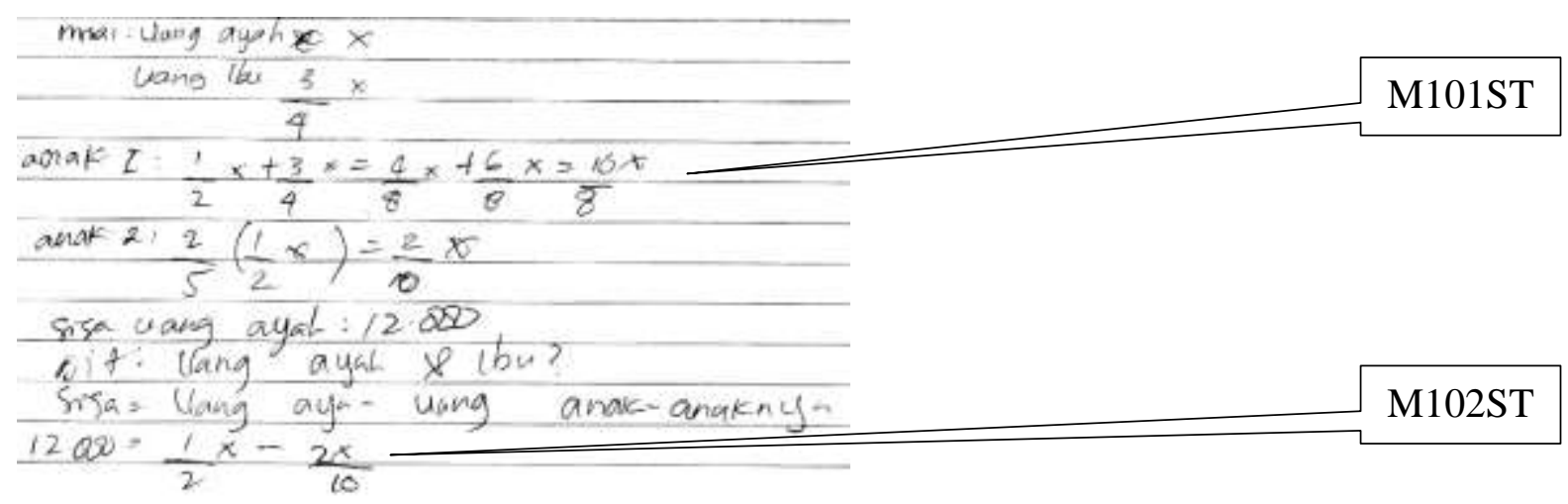

Gambar 1. Jawaban subjek ST dalam menyajikan masalah M1

Berdasarkan Gambar 1, menunjukkan bahwa ST menyajikan masalah kedalam berbagai bentuk representasi matematis diantaranya yaitu menyajikan yang diketahui (M101ST) dan menyajikan kedalam bentuk penyelesaian yaitu (M102ST). Selanjutnya peneliti melakukan wawancara dengan ST untuk memperoleh informasi lebih lanjut tentang pemahaman konsep ST pada masalah 1, sebagaimana kutipan berikut ini:

PN01M1: dari masalah ini apa yang kamu dapatkan dan apa yang kamu pahami ?

ST02M1: disoalnya ini uangnya ayah tidak diketahui jadi misalkan $\mathrm{x}$, kan uang ibu $\frac{3}{4}$ uang ayah jadi $\frac{3}{4} \mathrm{x}$

PN03M1: kemudian ini anak pertama kenapa $\frac{1}{2} \mathrm{x}+\frac{3}{4} \mathrm{x}$ ?

ST04M1: mana anak pertama

PN05M1: ini kan kamu tulis anak pertama $\frac{1}{2} \mathrm{x}+\frac{3}{4} \mathrm{x}$ ?

ST06M1: didalam soalnya kan anak pertama mendapatkan setengah dari uang ayah berarti setengah itu $\frac{1}{2}$ pak jadi $\frac{1}{2} \mathrm{x}$

PN07M1: kemudian kalau $\frac{3}{4}$ ?

ST08M1: terus dia mendapatkan tambahan uang uangnya ibu $\frac{3}{4}$ dari uangnya ayah jadi dia mendapatkan $\frac{3}{4} \mathrm{x}$

PN09M1: kemudian kalau anak kedua kan itu ada anak kedua kenapa disitu $\left(\frac{2}{5}\right)\left(\frac{1}{2} \mathrm{x}\right)$

ST10M1: anak kedua disini anak kedua mendapatkan $\frac{2}{5}$ dari sisa uang ayah, sisa uang ayahkan $\frac{1}{2} \mathrm{x}$ jadi dikali 
Hasil wawancara menunjukkan bahwa ST dapat menjelaskan alasan mengapa menyajikan masalah seperti kutipan wawancara diatas yaitu dengan menuliskan hal-hal yang diketahui (ST02M1, ST06M1, ST10M1). Sehingga dapat dikatakan bahwa ST mampu memberikan alasan dan menyajikan masalah kedalam berbagai bentuk representasi matematis.

Setelah menyajikan masalah, ST mengklasifikasi pecahan bentuk aljabar. Jawaban ST dalam mengklasifikasi pecahan bentuk aljabar sebagaimana ditunjukkan pada Gambar 2.

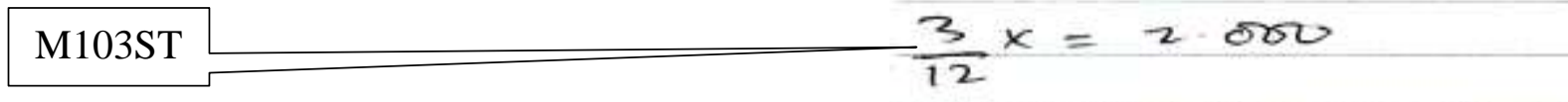

Gambar 2. Jawaban subjek ST dalam mengklasifikasi pecahan bentuk aljabar pada M1

Berdasarkan Gambar 2, ST mengelompokkan bentuk aljabar berdasarkan sifat pada aljabar yaitu memiliki variabel dan konstanta dengan benar (M103ST). Selanjutnya peneliti melakukan wawancara dengan ST untuk memperoleh informasi lebih lanjut tentang pemahaman konsep ST pada masalah 1, sebagaimana kutipan berikut ini:

PN53M1: dari masalah ini kamu lanjutkan kan ini $\frac{3}{10} \mathrm{x}=12.000$, kenapa kamu buat seperti itu?

ST54M1: terdiam, untuk cari nilai $\mathrm{x}$ nya pak $12.000=\frac{3}{10} \times$ diam lagi dikali 10 jadi $3 \mathrm{x}=$ $12.000 \times 10$

PN55M1: kemudian!

ST56M1: jadi $3 \mathrm{x}$ nya $=120.000$ kemudian semuanya dibagi 3 jadi $\mathrm{x}=\frac{120.000}{3}=40.000$, jadi uang ayah $=40.000$.

Hasil wawancara menunjukkan bahwa ST mengelompokkan konstanta dan variabelnya (ST54M1) sehingga ST dapat menemukan nilai x atau uang ayah (ST56M1). Sehingga dapat dikatakan bahwa ST mampu mengklasifikasikan variabel secara lisan dalam memahami masalah.

Setelah mengklasifikasi pecahan, ST memberi contoh pecahan aljabar dan non-contoh pecahan aljabar melalui wawancara dengan peneliti. Adapun kutipan wawancara ST dalam memberi contoh dan non-contoh pecahan aljabar sebagaimana di bawah ini.

PN11M1 : kemudian kamu tau tidak bentuk nya apa ? (sambil menunjuk)

$$
\begin{aligned}
& x-\frac{2}{3} x-\frac{1}{12} x \\
& \frac{1}{1} x-\frac{2 x}{3}-\frac{1 x}{12}
\end{aligned}
$$

ST12M1 : bentuk pecahan aljabar

PN13M1: kenapa dia dikatakan pecahan bentuk aljabar?

ST14M1 : karena ada koefisien dan variabelnya

PN15M1 : hmmmmm.... Kalau tidak ada variabelnya

ST16M1 : pecahan saja pak

Hasil wawancara menunjukkan bahwa ST dapat memberikan contoh dan non-contoh dari pecahan bentuk aljabar (ST12M1) disertai dengan alasan (ST14M1) dan sifat dari pecahan bentuk aljabar (ST14M1).

Setelah memberi contoh dan noncontoh pecahan aljabar, ST menangkap makna M1. Jawaban ST pada tahap menangkap makna M1 sebagaimana ditunjukkan pada Gambar 3. 


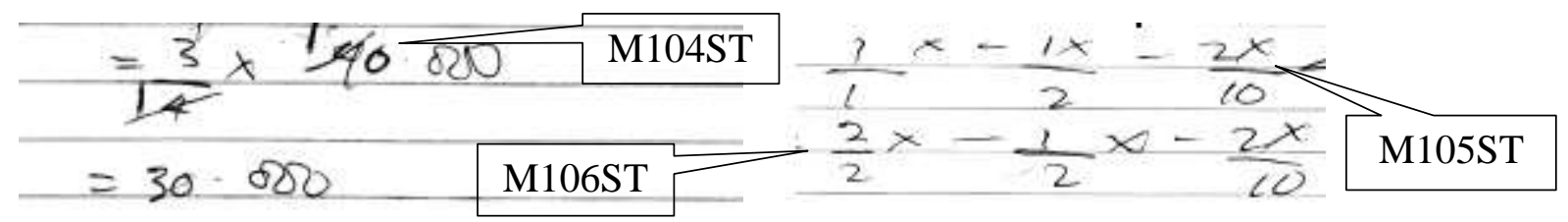

Gambar 3. Jawaban subjek ST dalam menangkap makna M1

Berdasarkan Gambar 3, ST menangkap makna suatu hukum kanselasi (M104ST), menangkap makna suatu pengurangan suku-suku sejenis dalam bentuk aljabar (M105ST) dengan suku sejenis yaitu $\mathrm{x}$, serta suatu operasi pengurangan pecahan (M106ST). Selanjutnya peneliti melakukan wawancara dengan ST untuk memperoleh informasi lebih lanjut tentang pemahaman ST pada masalah 1, sebagaimana kutipan berikut.

PN35M1 : sekarang setelah itu kenapa kamu tulis $\frac{1}{1}$ jadi $\frac{2}{2}$ ?

ST36M1 : kan disini penyebutnya berbeda-beda $\frac{1}{1} \mathrm{x}-\frac{1}{2} \mathrm{x}-\frac{2}{10} \mathrm{x}$ penyebutnya itu kan $1,2,10$ jadi dicari penyebut yang sama supaya bisa diselesaikan pak.

PN37M1 : oh berarti kamu cari penyebut yang sama?

ST38M1 : iyha pak.

PN39M1 : penyebut yang sama yang mana?

ST40M1 : 1 dan 2 penyebut yang sama 2

PN61M1 : disini saya lihat ada yang kamu coret, kenapa kamu coret?

ST62M1 : karena itu bisa dibagi langsung pak

PN63M1 : dibagi gimana?

ST64M1 : 4 dan 4 kan itu bisa dibagi dengan pembagian yang sama, jadi 4 dibagi 4 hasilnya 1

Hasil wawancara menunjukkan bahwa ST dapat menjelaskan alasan untuk menangkap makna suatu operasi-operasi pengurangan pecahan yang memiliki suku-suku sejenis (ST36M1) dan hukum kanselasi (ST64M1) pada operasi pecahan bentuk aljabar.

Langkah selanjutnya yaitu ST menjelaskan kembali operasi yang digunakan dengan menggunakan bahasa sendiri melalui wawancara dengan peneliti sebagaimana kutipan wawancara berikut ini:

PN35M1 : sekarang setelah itu kenapa kamu tulis $\frac{1}{1}$ jadi $\frac{2}{2}$ ?

ST36M1 : kan disini penyebutnya berbeda-beda beda $\frac{1}{1} \mathrm{x}-\frac{1}{2} \mathrm{x}-\frac{2}{10} \mathrm{x}$ penyebutnya itu kan $1,2,10$ jadi dicari penyebut yang sama supaya bisa diselesaikan pak.

PN37M1 : oh berarti kamu cari penyebut yang sama?

ST38M1 : iyha pak.

PN39M1 : penyebut yang sama yang mana?

ST40M1 : 1 dan 2 penyebut yang sama 2

PN41M1 : nach setelah itu kenapa bisa jawabanya $\frac{1}{2} \mathrm{x}$

ST42M1 : kan penyebut yang sama 2, 2:2 kan 1, 1x1 = 1

PN43M1 : sekarang disini, saya lihat $1 / 2 \times$ kenapa menjadi $\frac{5}{10} \times$ ?

ST44M1 : karena penyebutnya dulu disamakan, penyebutnya kan 2 dengan 10 disamakan penyebutnya $10,10: 2$ kan $5,1 \times 5=5$

PN45M1 : kenapa kamu ambil penyebutnya 10 kenapa bukan yang lain? 
ST46M1 : karena diperkalian begitu penyebutnya yang paling kecil 10.

PN47M1 : jadi kamu ambil yang kecilnya?

ST48M1 : ia pak.

PN61M1 : disini saya lihat ada yang kamu coret, kenapa kamu coret?

ST62M1 : karena itu bisa dibagi langsung pak

PN63M1 : dibagi gimana?

ST64M1 : 4 dan 4 kan itu bisa dibagi dengan pembagian yang sama, jadi 4 dibagi 4 hasilnya 1

PN65M1 : kemudian berapa kamu dapatkan?

ST66M1 : 30.000

Hasil wawancara menunjukkan bahwa ST dapat menjelaskan kembali operasi-operasi yang digunakan atau dimanfaatkan serta proses dalam memanfaatkan operasi atau suatu hukum yang digunakan.

Profil Pemahaman Konsep Operasi Pecahan Bentuk Aljabar Subjek Berkemampuan Sedang (SS).

Jawaban SS dalam menyajikan masalah sebagaimana ditunjukkan pada Gambar 4.

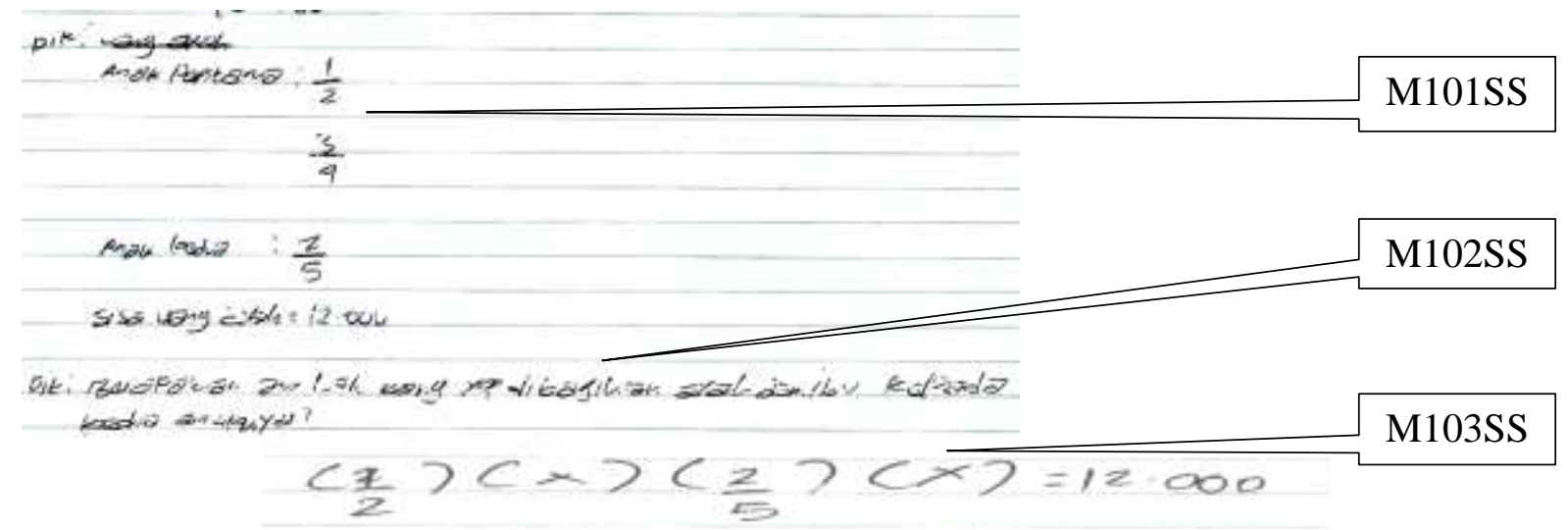

Gambar 4. Jawaban subjek SS dalam menyajikan M1

Berdasarkan Gambar 4, SS berusaha menyajikan masalah yang diketahui (M101SS), dan menyajikan yang ditanyakan (M102SS), serta penyajian masalah kedalam bentuk penyelesaian (M103SS). Sehingga dapat dikatakan bahwa SS menyajikan suatu masalah pecahan bentuk aljabar dalam berbagai bentuk representasi matematis, dengan menyajikan hal-hal yang diketahui kemudian menyajikannya kedalam bentuk matematika, walaupun dalam menyajikan masalah kedalam bentuk penyelesaian subjek masih mengalami kesulitan. Dalam rangka memperoleh informasi lebih lanjut tentang pemahaman SS pada M1, peneliti melakukan wawancara dengan SS sebagaimana kutipan berikut.

PN01M1 : Arman disini, bapak disini akan melakukan wawancara, bapak kan sudah memberikan sebuah masalah 1, nach kamu kan sudah menyelesaikan masalah yang bapak berikan, nach disini kamu kan menulis berapa yang kamu tulis?

SS02M1 : $\frac{1}{2}$ dikali $\mathrm{x}$ dikali $\frac{2}{5}$ dikali $\mathrm{x}=12.000$

PN03M1 : nach kenapa kamu tulis seperti ini ?

SS04M1 : karena $\frac{1}{2}$ adalah $\frac{1}{2}$ dari uang anak pertama yang diberikan oleh ayahnya 
PN05M1 : kenapa ada $\mathrm{x}$ ini?

SS06M1 : $\mathrm{x}$ adalah misalkan uang ayah $\mathrm{x}$, kan uang ayah adalah $\mathrm{x}$ jadi dimisalkan

PN07M1 : nach kalau $\frac{2}{5}$ ini kenapa?

SS08M1 : $\frac{2}{5}$ adalah uang anak kedua

PN09M1 : kalau x yang satunya?

SS10M1 : uang ayah

PN11M1 : uang ayah yang kamu misalkan juga?

SS12M1 : Ia

PN13M1 : nach kenapa $=12.000$

SS14M1 : nach karena sisa dari uang ayah

PN15M1 : sisa uang ayah memangnya berapa?

SS16M1 : 12.000

Hasil wawancara menunjukkan bahwa SS dalam menyajikan masalah kedalam bentuk representasi matematis, subjek SS menyajikan masalah yang diketahui kedalam pecahan bentuk aljabar (SS04M1, SS06M1).

Setelah menyajikan masalah, SS mengklasifikasikan pecahan aljabar. Jawaban SS dalam mengklasifikasi M1 sebagaimana Gambar 5.

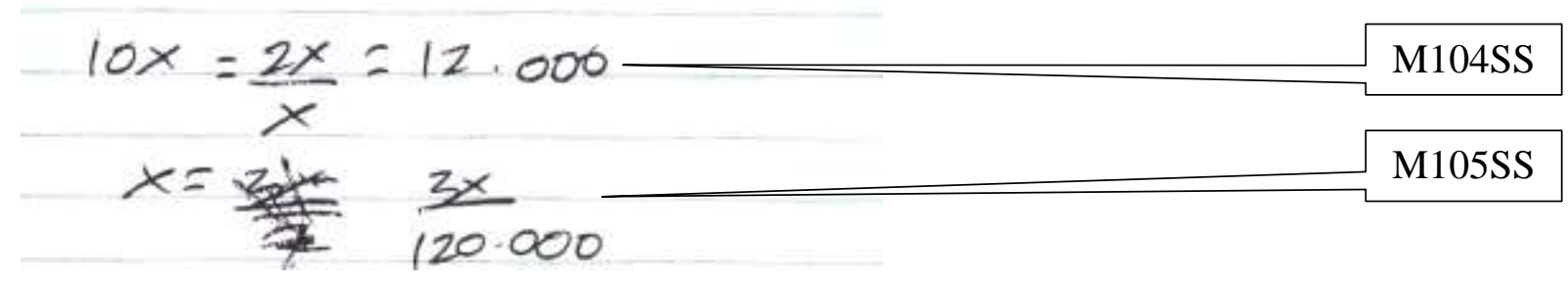

Gambar 5. Jawaban subjek SS dalam mengklasifikasi M1

Berdasarkan Gambar 5, SS berusaha mengelompokkan pecahan bentuk aljabar dengan variabel dan konstanta (M104SS), namun konsep pengelompokkan subjek SS masih kurang tepat (M105SS). Sehingga dapat dikatakan bahwa SS belum mampu mengelompokkan pecahan bentuk aljabar. Selanjutnya peneliti melakukan wawancara dengan SS untuk memperoleh informasi lebih lanjut tentang pemahaman konsep SS dalam menglasifikasi M1, sebagaimana kutipan berikut ini:

PN39M1 : hmmmm,,, kenapa ada dua sama denganya?

SS40M1 : (terdiam)

PN41M1 : kenapa?

SS42M1 : ini menurut saya $10 \mathrm{x}=2 \mathrm{x}$ dibahagi $\mathrm{x}=12.000$

PN43M1 : jadi karena itu kamu tulis 2 sama denganya

SS44M1 : iyha pak

Hasil wawancara menunjukkan bahwa SS belum mampu mengelompokkan pecahan bentuk aljabar (SS42M1). Subjek belum mampu menjelaskan alasan pengelompokkan, sehingga dapat disimpulkan bahwa subjek SS belum mampu mengelompokkan pecahan bentuk aljabar berdasarkan sifat sifat pada pecahan bentuk aljabar.

Setelah mengklasifikasi pecahan aljabar, SS menangkap makna M1 sebagaimana ditunjukkan pada Gambar 6. 


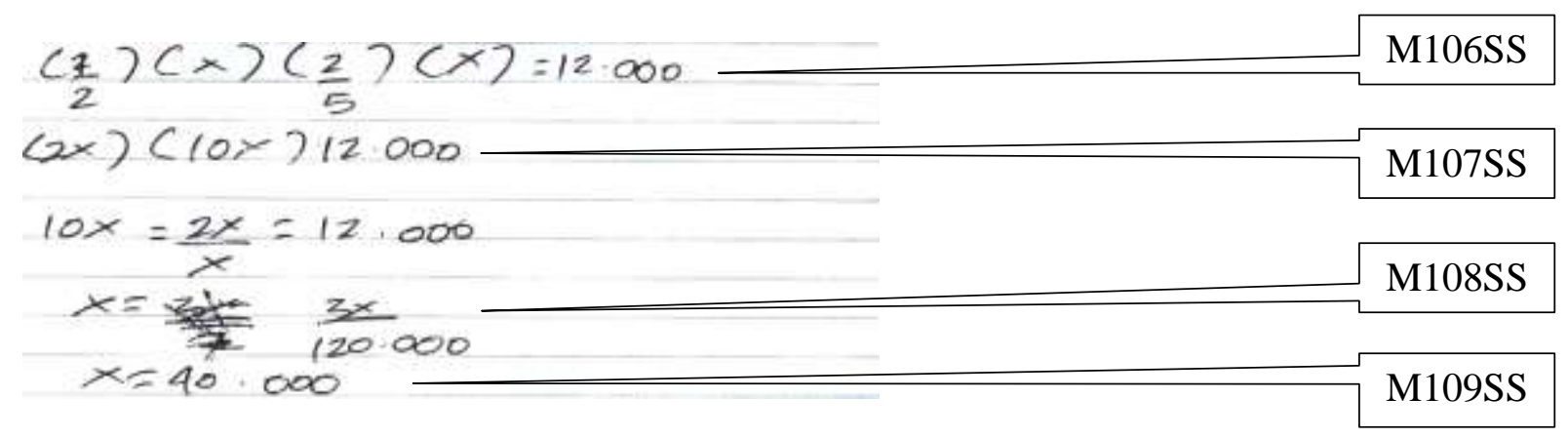

Gambar 6 Jawaban subjek SS dalam menangkap makna operasi M1

Berdasarkan Gambar 6, SS menangkap makna suatu operasi perkalian pecahan bentuk aljabar (M106SS) walaupun subjek masih mengalami kasalahan konsep dalam melakukan operasi perkalian pecahan bentuk aljabar (M107SS). Selain hal tersebut subjek juga menangkap makna suatu operasi pembagian pecahan bentuk (M108SS), walaupun subjek masih mengalami kesalahan konsep dalam melakukan operasi pembagian pecahan (M109SS). Dalam rangka memperoleh informasi lebih lanjut tentang pemahaman konsep SS dalam menangkap makna M1, peneliti melakukan wawancara dengan SS sebagaimana kutipan berikut.

PN21 M1 : nach disini kan selanjutnya, kamu mengerjakan bahwa ini kenapa hasilnya bisa $2 \mathrm{x}$

SS22 M1 : karena 2x1 $=2,2$ kali $\mathrm{x}=2 \mathrm{x}$

PN23 M1 : nach kalau yang $10 x$ ini?

SS24 M1 : karena $2 \times 5=10,10$ kali $\mathrm{x}=10 \mathrm{x}$

PN25 M1 : jadi begitu caranya kamu kalikan

SS26 M1 : ia pak

PN45 M1 : oh begitu, kemudian ini

SS46 M1 : $\mathrm{x}$, $\mathrm{x}$ nya turun kebawah $=2 \mathrm{x}$ dikali $\mathrm{x}=3 \mathrm{x}$ dibahagi 120.000

PN47 M1 : kenapa bisa dibahagi 120.000

SS48 M1 : karena 10x dikali $12.000=120.000$

PN49 M1 : oh iyha

SS50 M1 : jadi $=40.000$

PN51 M1 : kenapa bisa 40.000

SS52 M1 : karena 3x dibahagi 120.000 jadi hasilnya 40.000

Hasil wawancara menunjukkan bahwa SS menangkap makna suatu operasi perkalian (SS22M1, SS24M1, SS26M1) dan menangkap makna suatu operasi pembagian pecahan (SS52M1). Sehingga dapat dikatakan bahwa SS mampu menangkap makna suatu operasi yang digunakan atau dimanfaatkan dalam menyelesaikan suatu masalah.

Langkah selanjutnya yang dilakukan SS setelah menangkap makna M1 adalah menjelaskan kembali operasi atau makna yang digunakan melalui wawancara dengan peneliti sebagaimana kutipan wawancara berikut.

PN21M1 : nach disini kan selanjutnya, kamu mengerjakan bahwa ini kenapa hasilnya bisa $2 \mathrm{x}$

SS22M1 : karena $2 \times 1=2,2$ kali $\mathrm{x}=2 \mathrm{x}$

PN23M1 : nach kalau yang $10 \mathrm{x}$ ini?

SS24M1 : karena $2 \times 5=10,10$ kali $\mathrm{x}=10 \mathrm{x}$

PN25M1 : jadi begitu caranya kamu kalikan

SS26M1 : ia pak

PN45M1 : oh begitu, kemudian ini 
SS46M1 : $\mathrm{x}$, $\mathrm{x}$ nya turun kebawah $=2 \mathrm{x}$ dikali $\mathrm{x}=3 \mathrm{x}$ dibahagi 120.000

PN47M1 : kenapa bisa dibahagi 120.000

SS48M1 : karena 10x dikali $12.000=120.000$

PN49M1 : oh iyha

SS50M1 : jadi $\mathrm{x}=40.000$

PN51M1 : kenapa bisa 40.000

SS52 M1 : karena 3x dibahagi 120.000 jadi hasilnya 40.000

Hasil wawancara menunjukkan bahwa SS menjelaskan kembali makna operasi yang digunakan atau dimanfaatkan, namun dalam menjelaskan makna operasi yang digunakan atau dimanfaatkan subjek SS masih mengalami kesalahan konsep operasi perkalian pecahan (SS22M1, SS24M1) dan mengalami kesalahan konsep pembagian pecahan (SS52M1). Sehingga dapat dikatakan bahwa SS belum mampu menjelaskan dan memanfaatkan suatu operasi yang digunakan atau dimanfaatkan.

Profil Pemahaman Konsep Operasi Pecahan Bentuk Aljabar Subjek Berkemampuan Rendah (SR).

Jawaban subjek SR dalam menyajikan masalah, ditunjukkan sebagaimana Gambar 7.

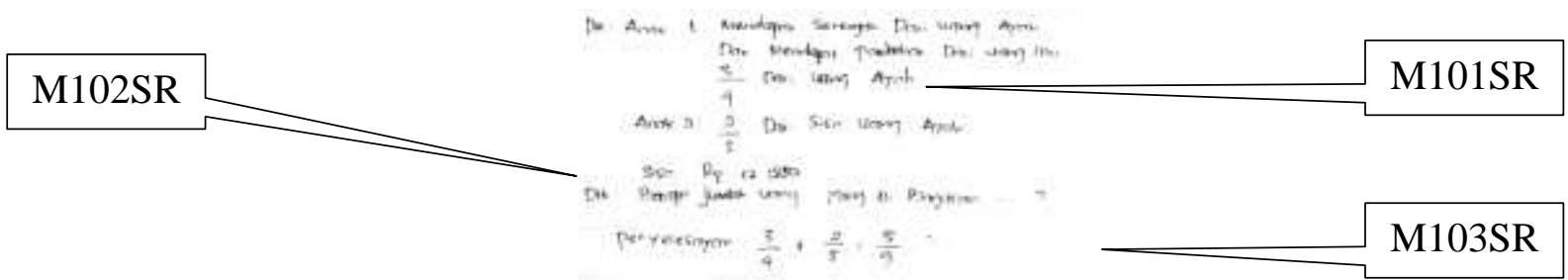

Gambar 7. Jawaban subjek SR dalam menyajikan masalah M1

Berdasarkan Gambar 7, SR menyajikan hal-hal yang diketahui dan ditanyakan (M101SR, M102SR), serta menyajikan masalah kedalam bentuk penyelesaian (M103SR). Sehingga dapat dikatakan bahwa SR dapat menyajikan masalah kedalam berbagai bentuk representasi matematis, walaupun subjek SR masih mengalami kesalahan dalam menyajikan masalah kedalam bentuk penyelesaian yaitu hanya berbentuk pecahan biasa.

Selanjutnya, peneliti melakukan wawancara dengan SR untuk memperoleh informasi lebih lanjut tentang pemahaman konsep SR dalam menyajikan masalah kedalam berbagai bentuk representasi matematis sebagaimana kutipan berikut.

PN01M1: dari masalah 1 yang bapak berikan apa yang kamu pahami?

SR02M1: dari anak pertama mendapatkan setengah dari uang ayah dan mendapatkan tambahan dari uang ibu

PN03M1: mendapatkan tambahan dari ibu sebesar berapa?

SR04M1: dari uang ayah ditambah uang ibu $\frac{3}{4}$

PN05M1: kemudian apa lagi yang kamu pahami?

SR06M1: Anak kedua mendapatkan $\frac{2}{5}$ dari sisa uang ayah

PN07M1: kemudian apa lagi yang kamu pahami, masi ada?

SR08M1: (terdiam)

PN08M1: apa yang kamu pahami?

SR09M1: uang yang tersisa 12.000

PN10M1: kemudian masih ada lagi yang kamu pahami? 
SR11M1: yang ditanyakan berapa jumlah uang yang dibagikan

PN12M1: siapa yang bagikan

SR13M1: yang dibagikan ayah dan ibu kepada kedua anaknya

PN14M1: nach kemudian, disini kan kamu menyelesaikanya, apa yang kamu, penyelesaianya gimana ini

SR15M1: anak pertama mendapatkan $\frac{3}{4}$ dari uang uang ibu dari ayah $+\frac{2}{5}$ dari sisa uang ayah yang diberikan kepada anak kedua

PN16M1: oh, jadi langsung kamu jumlahkan begitu?

SR17M1: iyha pak

Hasil wawancara menunjukkan bahwa SR menyajikan masalah kedalam berbagai bentuk representasi matematis, namun subjek SR masih mengalami kesalahan dalam menyajikanya yaitu masih kedalam bentuk pecahan biasa. Sehingga dapat dikatakan bahwa SR menyajikan pernyataan matematika secara lisan dan tertulis kedalam berbagai bentuk representasi matematis.

Setelah menyajikan masalah, SR menangkap makna M1 sebagaimana ditunjukkan pada Gambar 8 .

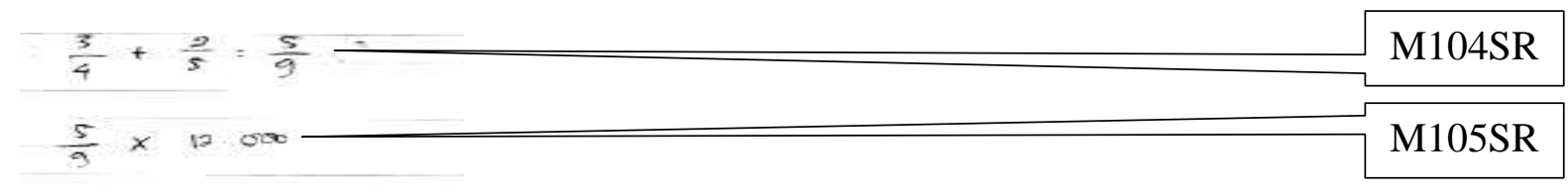

Gambar 8. Jawaban subjek SR dalam menangkap makna M1

Berdasarkan Gambar 8, SR menangkap makna suatu penjumlahan pecahan (M104SR), dan menangkap makna suatu perkalian pecahan (M105SR), walaupun dalam mengoperasikan penjumlahan pecahan SR masih kurang memahami konsep. Sehingga dapat dikatakan bahwa SR menangkap makna suatu penjumlahan dan perkalian pecahan dalam menyelesaikan suatu masalah.

Selanjutnya, peneliti melakukan wawancara dengan SR untuk memperoleh informasi lebih lanjut tentang pemahaman konsep SR dalam menangkap makna sebagaimana transkrip berikut:

PN14M1: nach kemudian, disini kan kamu menyelesaikanya, apa yang kamu, penyelesaianya gimana ini

SR15M1: anak pertama mendapatkan $\frac{3}{4}$ dari uang uang ibu dari ayah $+\frac{2}{5}$ dari sisa uang ayah yang diberikan kepada anak kedua

PN16M1: oh, jadi langsung kamu jumlahkan begitu?

SR17M1: iyha pak

Hasil wawancara menunjukkan bahwa SR menangkap makna suatu penjumlahan pecahan(SR15M1), namun subjek SR masih mengalami kesalahan dalam mengoperasikan penjumlahan pecahan. Sehingga dapat dikatakan bahwa SR menangkap makna suatu penjumlahan pecahan.

Langkah selanjutnya yang dilakukan SR setelah menangkap makna M1 adalah menjelaskan kembali operasi atau makna yang digunakan melalui wawancara dengan peneliti sebagaimana kutipan wawancara berikut.

PN14M1: nach kemudian, disini kan kamu menyelesaikanya, apa yang kamu, penyelesaianya gmna ini 
SR15M1: anak pertama mendapatkan $\frac{3}{4}$ dari uang uang ibu dari ayah $+\frac{2}{5}$ dari sisa uang ayah yang diberikan kepada anak kedua

PN16M1: oh, jadi langsung kamu jumlahkan begitu?

SR17M1: iyha pak

PN18M1: kemudian berapa kamu dapatkan

SR19M1: $\frac{5}{9}$

PN20M1: kenapa bisa $\frac{5}{9}$ ?

SR21M1: $3+2=5,4+5=9$

Hasil wawancara menunjukkan bahwa SR menjelaskan kembali makna operasi yang digunakan atau dimanfaatkan, namun dalam menjelaskan makna operasi yang digunakan atau dimanfaatkan subjek SR masih mengalami kesalahan konsep operasi penjumlahan pecahan (SR21M1). Sehingga dapat dikatakan bahwa SR belum mampu menjelaskan dan memanfaatkan suatu operasi yang digunakan atau dimanfaatkan.

\section{PEMBAHASAN}

Hasil analisis data hasil tes dan wawancara dalam memahami konsep pecahan bentuk aljabar berdasarkan indikator diperoleh pemahaman ST, SS dan SR sebagai berikut:

Berdasarkan hasil analisis data hasil tes dan wawancara dalam menyelesaikan masalah pecahan bentuk aljabar yaitu ST memanfaatkan indikator pemahaman konsep yang digunakan dalam penelitian ini yaitu mengklasifikasi pecahan bentuk aljabar yaitu subjek ST mengelompokkan pecahan bantuk pecahan yang memiliki variabel dan pecahan yang tidak memiliki variabel. Subjek ST memberi contoh pecahan bentuk aljabar dan non-contoh dari pecahan bentuk aljabar yakni subjek ST menjelaskan jenis pecahan bentuk aljabar yaitu memiliki variabel dan koefisien jika tidak memiliki variabel subjek ST menyatakan hanya berbentuk pecahan biasa. Subjek ST menyajikan suatu masalah pecahan bentuk aljabar dalam berbagai bentuk representasi matematis yaitu subjek ST menuliskan hal hal yang diketahui dan menuliskan hal yang diketahui tersebut kedalam bentuk matematika. Subjek ST menangkap makna berupa operasi-operasi pecahan bentuk aljabar yaitu subjek ST menangkap suatu makna operasi penjumlahan, pengurangan, perkalian pecahan suku-suku sejenis dan menangkap makna hukum kanselasi (penghapusan). Subjek ST Menjelaskan kembali suatu operasi-operasi yang digunakan atau dimanfaatkan dengan menggunakan bahasa sendiri yaitu subjek ST menjelaskan kembali operasi yang digunakan disertai dengan alasanya satu diantaranya yaitu operasi pengurangan pecahan bentuk aljabar. Berdasarkan hal tersebut ST dapat dikatakan telah memahami konsep dari pecahan bentuk aljabar. Sejalan dengan pernyataan Jaeng (2014:73) apabila pebelajar dapat mengklasifikasikan konstanta, koefisien dan variabel pada suatu persamaan serta dapat menggunakan rumus untuk menyelesaikan persamaan tersebut, maka kemampuan pebelajar sampai pada memahami konsep. Hal ini menunjukkan bahwa pentingnya pemahaman konsep dalam menyelesaikan suatu permasalahan matematika. Hal ini sejalan dengan pendapat Kesumawati (2008:233) bahwa dalam proses pembelajaran matematika, pemahaman konsep merupakan bagian yang sangat penting.

Berdasarkan hasil analisis data hasil tes dan wawancara dalam menyelesaikan masalah pecahan bentuk aljabar yaitu SS memanfaatkan tiga indikator pemahaman konsep yang digunakan dalam penelitian ini yaitu subjek SS menyajikan suatu masalah pecahan bentuk aljabar dalam berbagai bentuk representasi matematis dalam hal ini subjek SS menuliskan hal-hal yang 
diketahui dan menuliskannya kedalam bentuk penyelesaian matematika. Subjek SS menangkap makna berupa operasi-operasi pecahan bentuk aljabar yaitu menangkap makna suatu operasi perkalian dan pembagian pecahan bentuk aljabar. Kemudian subjek SS menjelaskan kembali operasi-operasi yang digunakan atau dimanfaatkan dengan menggunakan bahasa sendiri yaitu subjek SS menjelaskan kembali operasi perkalian dan pembagian pecahan bentuk aljabar yang digunakan walaupun dalam proses pelaksanaanya subjek SS masih belum memahami dengan baik konsep dari perkalian dan pembagian pecahan bentuk aljabar. Hal ini sejalan dengan pendapat Kumala (2014) bahwa dalam memahami sifat operasi hitung bilangan siswa seringkali salah dalam sifat operasi hitung. Sehingga dapat disimpulkan bahwa SS telah memahami konsep dari pecahan bentuk aljabar. Sejalan dengan pernyataan Jaeng (2014:73) apabila pebelajar dapat mengklasifikasikan konstanta, koefisien dan variabel pada suatu persamaan serta dapat menggunakan rumus untuk menyelesaikan persamaan tersebut, maka kemampuan pebelajar sampai pada memahami konsep.

Berdasarkan hasil analisis data hasil tes dan wawancara dalam menyelesaikan masalah pecahan bentuk aljabar yaitu SR menggunakan dua indikator pemahaman konsep yang digunakan dalam penelitian ini yaitu: subjek SR menyajikan suatu masalah pecahan bentuk aljabar dalam berbagai bentuk representasi matematis, dalam hal ini subjek SR menuliskan hal-hal yang diketahui kemudian menuliskan bentuk penyelesaiannya kedalam bentuk matematika, walaupun subjek SR masih mengalami kesalahan dalam memaparkan pemecahan masalah kedalam bentuk matematika, yaitu subjek SR masih menuliskan kedalam bentuk pecahan biasa. Subjek SR menangkap makna berupa operasi-operasi pecahan yaitu menangkap makna suatu operasi penjumlahan, perkalian, dan pembagian pecahan. Sehingga dapat disimpulkan bahwa pemahaman konsep SR pada materi pecahan bentuk aljabar masih rendah.

Berdasarkan uraian tersebut diperoleh profil pemahaman konsep ST, SS, dan SR dalam menyelesaikan operasi pecahan bentuk aljabar berdasarkan indikator pemahaman konsep yaitu dalam menyajikan suatu masalah. Subjek berkemampuan tinggi, sedang dan rendah menuliskan hal-hal yang diketahui, ditanyakan dan menuliskan hal yang diketahui tersebut kedalam bentuk matematika. Namun SR salah dalam memahami masalah disebabkan karena kurangnya ketelitian dalam memahami masalah. Hal ini sejalan dengan pernyataan Hartini (2008) yang menyatakan subjek salah dalam menuliskan yang diketahui yang disebabkan kurangnya ketelitian subjek. Selanjutnya dalam mengklasifikasi pecahan bentuk aljabar subjek ST dan SR mengelompokkan pecahan yang memiliki variabel dan pecahan yang tidak memiliki variabel. Sehingga dapat dikatakan bahwa subjek SR dan ST memahami konsep dengan baik dalam menyajikan masalah pecahan bentuk aljabar. Sejalan dengan pernyataan Jaeng (2014:73) apabila pebelajar dapat mengklasifikasikan konstanta, koefisien dan variabel pada suatu persamaan serta dapat menggunakan rumus untuk menyelesaikan persamaan tersebut, maka kemampuan pebelajar sampai pada memahami konsep. Kemudian dalam memberi contoh pecahan bentuk aljabar dan non-contoh dari pecahan bentuk aljabar. ST menjelaskan jenis pecahan bentuk aljabar yaitu memiliki variabel dan koefisien jika tidak memiliki variabel subjek ST menyatakan hanya berbentuk pecahan biasa selain hal tersebut subjek ST juga menunjukkan dengan tepat yang merupakan pecahan bentuk aljabar.

Kemudian dalam menangkap makna suatu masalah, subjek ST menangkap suatu makna operasi penjumlahan, pengurangan, perkalian pecahan suku-suku sejenis dan menangkap makna hukum kanselasi (penghapusan). Subjek SS menangkap makna berupa operasi-operasi pecahan bentuk aljabar yaitu menangkap makna suatu operasi perkalian dan pembagian pecahan bentuk aljabar. Subjek SR menangkap makna berupa operasi-operasi pecahan yaitu menangkap makna suatu operasi penjumlahan, perkalian, dan pembagian pecahan. Setelah menangkap makna subjek menjelaskan kembali suatu objek-objek, sifat-sifat dan fakta serta 
operasi-operasi tertentu yang digunakan atau dimanfaatkan. Subjek ST menjelaskan kembali operasi yang digunakan disertai dengan alasanya satu diantaranya yaitu operasi pengurangan pecahan bentuk aljabar dengan baik. subjek SS menjelaskan kembali operasi perkalian dan pembagian pecahan bentuk aljabar yang digunakan walaupun dalam proses pelaksanaanya subjek SS masih belum memahami dengan baik konsep dari perkalian dan pembagian pecahan bentuk aljabar. Hal ini sejalan dengan pendapat Kumala (2014) bahwa dalam memahami sifat operasi hitung bilangan siswa seringkali salah dalam sifat operasi hitung.

\section{KESIMPULAN}

Hasil penelitian ini menunjukkan bahwa dalam menyelesaikan masalah operasi pecahan bentuk aljabar, subjek berkemampuan matematika tinggi, sedang dan rendah memiliki pemahaman yang berbeda-beda. Subjek berkemampuan tinggi memahami dengan baik lima indikator pemahaman konsep yaitu menyajikan masalah, mengklasifikasi pecahan aljabar, memberi contoh dan non-contoh pecahan aljabar, dan menangkap makna masalah, serta menjelaskan kembali operasi yang digunakan atau dimanfaatkan dengan menggunakan bahasa sendiri. Hal ini menunjukkan bahwa subjek berkemampuan matematika tinggi memiliki pemahaman konsep yang baik. Subjek berkemampuan matematika sedang memahami dua indikator pemahaman konsep dengan baik yaitu menyajikan masalah dan menangkap makna masalah, walaupun dalam proses pelaksanaan operasi-operasi subjek berkemampuan sedang masih sering mengalami kesalahan. Hal ini menunjukkan bahwa subjek berkemampuan matematika sedang memiliki pemahaman yang cukup, sedangkan subjek berkemampuan matematika rendah kurang memahami konsep dengan baik dalam menyelesaikan suatu operasi pecahan bentuk aljabar. Dalam hal ini subjek berkemampuan rendah memanfaatkan dua indikator pemahaman konsep yaitu menyajikan masalah dan menangkap makna masalah, namun subjek berkemampuan rendah masih menyajikan masalah kedalam pecahan biasa dan hanya menangkap makna penjumlahan pecahan biasa. Hal ini menunjukkan bahwa subjek berkemampuan matematika rendah memiliki pemahaman konsep masih sangat rendah.

\section{SARAN}

Berdasarkan kesimpulan dan hasil penelitian ini hendaknya dalam mengajar matematika, seorang guru lebih memperhatikan pemahaman konsep siswa, sehingga untuk materi yang berkelanjutan siswa tidak akan terlalu kesulitan dalam mempelajari materi selanjutnya. Selain itu jika pemahaman konsep siswa tidak ditingkatkan maka siswa akan mengalami kesulitan dalam menyelesaikan masalah matematika. Serta dalam proses pembelajaran sebaiknya lebih menekankan pada proses pembelajaran kebermaknaan dan pemahaman konsep sehingga konsep dasar siswa bisa lebih baik.

\section{DAFTAR PUSTAKA}

Endah S. M, Mardiyana, Subanti S. (2016). analisis miskonsepsi siswa pada materi pecahan dalam bentuk aljabar ditinjau dari gaya kognitif siswa kelas viii di smp negeri 2 adimulyo kabupaten kebumen tahun ajaran 2013/2014. Jurnal Elektronik Pembelajaran Matematika. Vol.4, No.4, hal 401-413 Juni 2016. Prodi Magister Pendidikan Matematika, FKIP Universitas Sebelas Maret Surakarta ISSN: 2339-1685. [online]. Tersedia:http://jurnal.fkip.uns.ac.id/index.php/s2math [09 Desember 2016]. 
Hartini.(2008). Analisis Kesalahan Siswa Menyelesaikan Soal Cerita pada Kompetensi Dasar Menemukan Sifatdan Menghitung Besaran-besaran Segi Empat Siswa Kelas VII Semester II SMP It Nur Hidayah Surakarta Tahun Pelajaran 2006/2007. Tesis Magister pada Program Pasca Sarjana Universitas Sebelas Maret Surakarta. Surakarta: diterbitkan. Tersedia: http://core.ac.uk /download/pdf/16508001.pdf [23 April 2017].

Jaeng M. (2014). Teori Belajar dan Inovasi Pembelajaran Matematika. Program Studi Pendidikan Matematika. FKIP. Universitas Tadulako.

Kesumawati, N. (2008). Pemahaman Konsep Matematik dalam Pembelajaran Matematika. Semnas Matematika dan Pendidikan Matematika, Vol. 1 No. 1. [Online]. Tersedia:http://eprints.uny.ac. id/6928/1/P-18\%20Pendidikan\%28 Nila\%20K\%29.pdf [23 April 2017].

Kumala D, S , I. (2014). Analisis Kesalahan Siswa Kelas VIII Dalam Menyelesaikan Soal Pada Materi Faktorisasi Bentuk Aljabar SMP Negeri 1 Kamal Semester Gasal Tahun Ajaran 2013/2014. Jurnal Ilmiah Pendidikan Matematika MATHEdunesa.Vol.3, no 2. [online]. Tersedia: http://ejournal.unesa.ac.id/article/11690/30/article.pdf . [29 maret 2017]

Kumalasari \& Putri. (2013). Kesulitan Belajar Matematika Siswa Ditinjau dari Segi Kemampuan Koneksi Matematika. Prosiding Seminar Nasional Matematika dan Pendidikan Matematika Universitas Negeri Yogyakarta. ISBN: 978-979-16353-9-4. [Online]. Tersedia: http://eprints.uny.ac.id/ 10725/1/P\%20-\%202.pdf [08 Oktober 2016]

Miles, M. B. dan Huberman, A. M. (1992). Analisis Data Kualitatif: Buku Sumber Tentang Metode-metode Baru. Terjemahan oleh Tjeptjep Rohendi Rohidi. Jakarta: UI-Press

Soedjadi, R. (1999). Kiat Pendidikan Matematika di Indonesia (Konstatasi Keadaan Masa Kini Menuju Harapan Masa Depan). Jakarta: Ditjen Dikti Depdikbud.

Utari,Vivi. (2012). peningkatan kemampuan pemahaman konsep melalui pendekatan pmr dalam pokok bahasan prisma dan limas. Jurnal Pendidikan Matematika FMIPA UNP. Vol. 1 No. 1 (2012).[online].Tersedia:http://Fejournal.unp.ac.id\%2Fstudents\%2Findex.php\%2Fpmat\%2Farticle\%2Fdownload\%2F1159\%2F851\&usg=AFQjCNEG3BZ8xr-Ofg0V0LjIaKt0ldyikg.[01 November 2016].

Yuanda, S.M., Armiati., dan Mirna. (2014). Pengaruh Pembelajaran Kooperatif Tipe Think Pair Square Terhadap Pemahaman Konsep Matematika Siswa Kelas Xi IPA Sma Adabiah Padang. Jurnal pendidikan matematika part 1. Vol 3. No 3. [Online]. https://journal.unp.ac.id\%2Fstudents\%2Findex.php\%2Fpmat $\% 2$ Farticle $\% 2$ Fdownload\% 2F1327.pdf [16 Mei 2017] 